DOI:

Юлія Ляховська, аспірантка Уманського державного педагогічного університету імені Павла Тичини

\title{
МЕТОДОЛОГІЧНІ ПІДХОДИ ДО ФОРМУВАННЯ ГРОМАДЯНСЬКОЇ КУЛЬТУРИ В МАЙБУТНІХ УЧИТЕЛІВ ІНОЗЕМНОЇ МОВИ
}

У статті розкрито основні компоненти реалізації методологічних підходів як стратегії дослідження і побудови педагогічної концепції розвитку громадянської культури майбутнього вчителя іноземної мови: системного, особистісноорієнтованого, культурологічного, полікультурного, діяльнісного. Встановлено, щзо схарактеризовані підходи забезпечують на достатньому, з погляду визначених суспільством вимог, рівні розв'язання проблеми формування громадянської культури майбутнього вчителя іноземної мови.

Ключові слова: методологічні підходи; формування; громадянська культура; майбутні учителі; іноземна мова

Табл. 6. Літ. 22.

Yuliia Liakhovska, Postgraduate Student, Uman Pavlo Tychyna State Pedagogical University

\section{METHODOLOGICALAPPROACHES TO THE FORMATION OF CIVIC CULTURE OF FUTURE FOREIGN LANGUAGE TEACHERS}

The main components of realization of methodological approaches as strategy of research and construction of pedagogical concept of development of civic culture of the future teacher of a foreign language are revealed in the article: system, personality-oriented, culturological, multicultural, activity. The relevance, essence, manufacturability of each approach are revealed. Their effectiveness is proved: the system approach allows to analyze, investigate, develop the studied object as a holistic, unified system of interconnected structures: semantic, procedural and effective; the result of the axiological approach: the formation of value principles of relations between people as citizens (value principles of civil relations), the development of civic position; the implementation of a personalityoriented approach helps to reveal the individuality of each applicant, assumes that the focus is on the student's personality. The system of civil, legal, moral norms and measures of the educational process are addressed to it; culturological approach in teaching a foreign language is as follows: the essential features of socio-cultural structures are revealed in the comparative study of languages and national pictures of the world; the contrast of English and Ukrainian socio-cultural situations is manifested in the comparison of the national mentality of both cultures. Solving the problems of intercultural communication is associated with understanding the need to teach a foreign language based on the native language and culture; the result of applying a multicultural approach: a person of culture, a creative person with an active civic position, capable of active and productive life in a multicultural environment; the implementation of the activity approach awakens the creative potential of applicants, as well as stimulates them to solve various problems independently.

It is established that the characterized approaches provide sufficient, from the point of view of the requirements determined by the society, levels of the decision of a problem of formation of civil culture of the future teacher of a foreign language.

Keywords: methodological approaches; formation; civic culture; future teachers; foreign language.

П остановка проблеми. Трансформаційні процеси, що відбуваються у світовому співтоваристві, проявляються у взаємозалежності суспільного прогресу та освіти, що надає його досягненням і проблемам особливої актуальності. Проблема ця набуває особливої значущості у звјязку з поширенням ідей гуманізації і гуманітаризації освіти, перебудови освітнього процесу.

Важливе місце в означеному процесі займають вчителі-практики, покликані забезпечувати ефективну діяльність закладів загальної середньої освіти. Це гарантує успішність виконання соціального замовлення держави і потреб суспільства 3 підготовки гуманних, компетентних, конкурентоспроможних фахівців.

Система підготовки майбутніх учителів, зокрема вчителів іноземної мови, - це складний, цілісний процес, показником результативності якого є здатність грамотно розв'язувати професійні завдання.

Аналіз основних досліджень. Аналіз літератури 3 досліджуваної проблеми дозволяє намітити підходи, необхідні до практичної реалізації поставлених завдань: системний (О. Рогульська [18], Н. Дерев'янко [4], Л. Огородник [15]); особистісноорієнтований (Т. Мироненко [12], М. Михайліченко [13]); 


\begin{tabular}{|c|c|}
\hline \multicolumn{2}{|c|}{$\begin{array}{c}\text { Реалізація системного підходу у процесі формування громадянської культури } \\
\text { майбутнього вчителя іноземної мови }\end{array}$} \\
\hline Трактування & $\begin{array}{l}\text { Системний підхід до формування громадянської культури майбутніх педагогів } \\
\text { дозволив розглядати цей процес як єдину систему і зосередити увагу на виявленні } \\
\text { різноманітних зв’язків і відносин, що мають місце як усередині досліджуваного } \\
\text { об’єкта, так і в його взаєминах із зовнішнім оточенням і зовнішнім середовищем. }\end{array}$ \\
\hline Актуальність & $\begin{array}{l}\text { Системний підхід відображає загальний зв’язок і взаємообумовленість явищ i } \\
\text { процесів навколишньої дійсності і дозволяє розглядати будь-яке явище як систему, в } \\
\text { якій відносно самостійні компоненти не ізольовані, знаходяться у взаємозв’язку і } \\
\text { розвитку, їх взаємодія обумовлює наявність таких інтеграційних системних } \\
\text { властивостей і якісних характеристик, які відсутні у складових системи елементів. }\end{array}$ \\
\hline Мета & $\begin{array}{l}\text { За допомогою системного підходу можна розглядати не тільки об’єкт як систему, а й } \\
\text { процеси його функціонування i розвитку, а також процеси управління } \\
\text { компонентами, або всією системою. У зв’язку } 3 \text { цим, системний підхід має } \\
\text { найважливішу якість - універсальність, що дозволяє цю якість зіставити } 3 \\
\text { цілісністю об'єкта дослідження }\end{array}$ \\
\hline Технології & $\begin{array}{l}\text { Системний підхід дозволяє проаналізувати, дослідити, розвивати певний об’єкт як } \\
\text { цілісну, єдину систему. Він орієнтує на розкриття цілісності об’єкта, на виявлення } \\
\text { істотних зв’язків і відносин між елементами об’єкта, які забезпечують його } \\
\text { внутрішню організацію, функціонування і розвиток. }\end{array}$ \\
\hline Результат & $\begin{array}{l}\text { Системний підхід є надійною методологічною основою вдосконалення педагогічної } \\
\text { теорії і практики формування громадянської культури майбутніх учителів іноземної } \\
\text { мови, дозволяє проаналізувати, дослідити, розвивати досліджуваний об'єкт як } \\
\text { цілісну, єдину систему взаємопов’язаних структур: змістову, процесуальну та } \\
\text { результативну. }\end{array}$ \\
\hline
\end{tabular}

культурологічний, (Г. Ерме [19], L. Barmer [20]); полікультурний (Р. Кравець [8], Д. Демченко [3], І. Жадан [5], Н. Подковирофф [16], С. Радул [17], N.Bilbeny[21],D. Gollnick[22];діяльнісний(А. Асмолов [1], Е. Макарова [9], С. Москаленко [14]). Виокремлені науковцями методологічні підходи $€$ базовими для формування громадянської культури в майбутніх учителів іноземної мови.

Мета дослідження - розкрити основні компоненти реалізації методологічних підходів (актуальність, сутність, технологічність, результат) як стратегії дослідження і побудови педагогічної концепції розвитку громадянської культури майбутнього вчителя іноземної мови: системного, особистісноорієнтованого, культурологічного, полікультурного, діяльнісного.

Виклад основного матеріалу. Доцільність застосування системного підходу в освітньому процесі полягає у тому, що: а) він сприяє не тільки розвитку в цілісному освітньому процесі, а й формуванню глибинних професійних знань і на цій основі міцних особистісних якостей здобувача вищої освіти як особистості: внутрішнє професійне переконання, науковий світогляд, моральна цілісність, особистісний морально-психологічний, моральний стрижень фахівця; б) системний підхід дає змогу моделювати умови для самореалізації і самовираження здобувача $[10,119]$.

Детальна характеристика основних аспектів системного підходу подана у таблиці 1.
У світлі ідей системного підходу індивідуальна діяльність вчителя іноземної мови як педагогічна система становить взаємозвјязок структурних і функціональних елементів, підпорядкування цілям формування кваліфікованого фахівця, здатного продуктивно розв'язувати освітні завдання і нести відповідальність за якість цих рішень в умовах самостійної діяльності $[11,59]$.

Системний підхід у процесі формування цінностей громадянськості і патріотизму обумовлений самою природою означеного соціально-педагогічного явища, яке, як і інше будьяке соціальне явище, існує як взаємозалежна цілісна сукупність елементів $[9,106]$.

Використовуючи системний підхід, можна припустити чітку постановку проблеми, визначити засоби для ії вирішення, що сприятиме поліпшенню організації дослідження, розробити педагогічну модель формування громадянської культури майбутніх учителів іноземної мови.

Розгляд освітнього процесу з погляду реалізації аксіологічного підходу дав змогу виявити напрями у застосуванні аксіологічного підходу: 1) вивчення, проєктування і організація освітнього процесу, оріснтованого на розвиток здобувача як цілісності; 2) вивчення, проєктування і організація освітнього процесу, орієнтованого на виникнення у майбутнього вчителя певних особистісних цінностей і розвиток їх ціннісного світу; 3) підготовка майбутнього вчителя в системі професійної освіти, 


\section{МЕТОДОЛОГІЧНІ ПДХОДИ ДО ФОРМУВАННЯ ГРОМАДЯНСЬКОЇ КУЛЬТУРИ В МАЙБУТНІХУЧИТЕЛІВ ІНОЗЕМНОӤ МОВИ}

що передбачає включення нормативно заданих ціннісних засад професійної педагогічної діяльності до системи особистісних цінностей майбутнього педагога.

Знання про цінності необхідні при вирішенні таких педагогічних проблем: 1) визначення ціннісних засад професійної педагогічної діяльності, спрямованої на побудову полікультурної освіти, орієнтованих на розвиток громадянських якостей людини; 2) розробка механізмів включення нормативно заданих ціннісних засад професійної педагогічної діяльності в систему особистісних цінностей педагогів; 3) визначення цілей, змісту і способів організації громадянської освіти, орієнтованих на виникнення громадянськополітичних цінностей майбутнього вчителя i розвиток їх громадянської позиції $[7,131]$.

Орієнтація освіти на розвиток особистісно значущих цінностей майбутніх фахівців, що характеризується як процес їх універсалізації, передбачає, що реалізація цієї функції освіти може бути здійснена тільки в цілісному освітньому процесі, що забезпечує взаємоповјязаний i взаємозумовлений розвиток як основних сторін розвитку людини, так і розвиток всіх елементів іiі особистісного і професійного досвіду.

Характеристика основних аспектів аксіологічного підходу подана у таблиці 2.

В. Журова вважає за необхідне спиратися на аксіологічний підхід, який дає можливість підійти до процесу становлення громадянської компетентності студентської молоді через ствердження основоположних громадянських цінностей, усвідомлення і оцінку себе як громадянина $[6,46]$.

Аксіологічний (ціннісний) підхід визначає оновлення ціннісних орієнтацій соціуму і спрямованість на формування суспільного ідеалу особистості [14, 125].

I. Вахрушева розглядає аксіологічний підхід в освітньому процесі як сукупність педагогічних прийомів, що мають на меті актуалізувати ціннісне ставлення до досліджуваного матеріалу [2, 39].

Аналіз наукової літератури допоміг розуміти під аксіологічним підходом таке бачення майбутнього вчителя через призму цінностей, яке дозволяє розглядати його в освітньому процесі як складну інтегративну особистість, детерміновану

Таблиця 2.

Реалізація аксіологічного підходу у процесі формування громадянської культури майбутніх учителів іноземної мови

\begin{tabular}{|c|c|}
\hline Трактування & $\begin{array}{l}\text { Аксіологічний підхід до розвитку громадянської культури майбутнього вчителя на } \\
\text { конкретно-науковому рівні дозволяє уточнити цілі педагогічної концепції розвитку } \\
\text { громадянської позиції майбутнього вчителя, її зміст, ряд принципів громадянської } \\
\begin{array}{l}\text { освіти, а також вказує на закономірності вибору технології розвитку } \\
\text { досліджуваного феномена }\end{array}\end{array}$ \\
\hline Актуальність & $\begin{array}{l}\text { Актуальність застосування підходу обгрунтована зміненими вимогами до якісних } \\
\text { характеристик соціальної позиції майбутнього вчителя, новим підходом до змісту } \\
\text { громадянської освіти, а також розробкою і послідовною реалізацією } \\
\text { полікультурної концепції в сучасній вищій школі }\end{array}$ \\
\hline Мета & $\begin{array}{l}\text { Мета застосування аксіологічного підходу: становлення складної інтегративної } \\
\text { особистості, детермінованої віковими і психологічними особливостями, що обирає } \\
\text { суспільно значущі і професійні цінності як особисті, що визначають активність їі } \\
\text { (особистості) громадянської позиції }\end{array}$ \\
\hline Термінологія & $\begin{array}{l}\text { Понятійно-термінологічний апарат аксіологічного підходу: 1) розглядається як те, } \\
\text { що людиною переживається як значуще саме по собі і як те, що визначає } \\
\text { спрямованість ії активності; 2) інтеріоризація - становлення форми психіки, } \\
\text { завдяки освоєнню індивідом людських цінностей; 3) аксіологічний онтологізм - } \\
\text { теорія, яка розуміє свідомість людини, що сприймає світ як цілісність, як джерело } \\
\text { виникнення цінностей; 4) аксіологічний компонент змісту освіти - обов'язковий } \\
\text { компонент змісту вищої освіти, імпліцитно міститься у всіх дисциплінах }\end{array}$ \\
\hline Технології & $\begin{array}{l}\text { Аксіологічні засади технологій громадянської освіти 1) з позицій даного підходу } \\
\text { педагогічні технології формування громадянської культури майбутнього фахівця } \\
\text { не будуть нав’язуватися “зверху”, а забезпечать свободу вибору і будуть } \\
\text { зорієнтовані на соціальне самовизначення студентів, озброєних вміннями } \\
\text { співвідносити отримані знання з фактами і подіями реального життя, правильно їх } \\
\text { використовувати і самостійно поповнювати; 2) технології громадянської освіти в } \\
\text { ЗВО базуються на соціокультурній діагностиці }\end{array}$ \\
\hline Результат & $\begin{array}{l}\text { Результат застосування аксіологічного підходу: формування ціннісних засад } \\
\text { відносин між людьми як громадянами (ціннісних засад громадянських відносин), } \\
\text { розвиток громадянської позиції. }\end{array}$ \\
\hline
\end{tabular}




\section{МЕТОДОЛОГІЧНІ ПДХОДИ ДО ФОРМУВАННЯ ГРОМАДЯНСЬКОЇ КУЛЬТУРИ В МАЙБУТНТХ УЧИТЕЛІВ ІНОЗЕМНОЇ МОВИ}

віковими і психологічними особливостями, яка обирає суспільно значущі і професійно-педагогічні цінності як особисті, що визначають активність його громадянської позиції.

Особистісноорієнтований підхід має на увазі розкриття можливостей індивіда, становлення самосвідомості; саморозвиток особистості визначається соціальною значимістю, оскільки ідея формування соціально-політично активного громадянина будується на взаємозв'язку громадського та індивідуального благополуччя.

Характеристика основних аспектів особистісноорієнтованого підходу подана у таблиці 3.

Практична реалізація означеного підходу в організації процесу формування громадянської культури здобувачів у сучасному педагогічному ЗВО передбачає передовсім: постійне вивчення i добре знання індивідуальних особливостей здобувача, його поглядів та ін.; вміння діагностувати реальний рівень сформованості особистісних якостей майбутнього педагога; організацію діяльності, що забезпечує особистісний розвиток людини; створення умов для самовиховання і саморозвитку особистості здобувача; розвиток самостійності, ініціативності, вміння спрямовувати діяльність, що призводить до успіху.

Використання культурологічного підходу передбачає опору в освітньому процесі ЗВО на національні традиції народу, вивчення здобувачами вищих досягнень національних культур і всієї світової культури, що є вищим проявом творчих сил і здібностей людини.

Характеристика основних аспектів культурологічного підходу подана у таблиці 4.

Культурологічний підхід може успішно інтегруватися 3 іншими варіантами реалізації громадянської освіти, насамперед це стосується формування правової і політичної культури.

Звернення до потенціалу полікультурного підходу в процесі формування громадянської культури майбутнього вчителя іноземної мови пояснюється тим, що процес професійної підготовки, який є методологічною базою формування громадянської позиції, системи особистісних пріоритетів і цінностей майбутнього вчителя, готового до професійної діяльності в полікультурному освітньому просторі, а також програми громадянської освіти здобувачів 3ВО, весь методичний супровід до них розроблений без урахування полікультурного простору життєдіяльності особистості $[7,120]$.

Основні компоненти реалізації полікультурного підходу як стратегії дослідження і побудови педагогічної концепції розвитку громадянської культури майбутнього вчителя представлені в таблиці 5.

Таблиця 3.

Реалізація особистісно-оріснтованого підходу у процесі формування громадянської культури майбутнього вчителя іноземної мови

\begin{tabular}{|c|c|}
\hline Трактування & $\begin{array}{l}\text { Особистісно-орієнтований підхід застосовується як комплексне утворення, що } \\
\text { складається } 3 \text { понять, принципів і способів педагогічних (виховних) дій, як } \\
\text { методологічна орієнтація педагогічної діяльності викладача, яка за допомогою } \\
\text { опори на систему взаємопов'язаних понять, ідей і способів дій забезпечує і } \\
\text { підтримує процеси самопізнання, самореалізації особистості учня, розвиток його } \\
\text { індивідуальності і прояву суб'єктних якостей здобувача }\end{array}$ \\
\hline Актуальність & $\begin{array}{l}\text { Особистісно-орієнтований підхід потребує побудови навчального процесу } 3 \\
\text { урахуванням особистісних диспозицій і мотиваційних конструктів суб'єктів } \\
\text { навчання. }\end{array}$ \\
\hline Мета & $\begin{array}{l}\text { Особистісно-орієнтований підхід дозволяє розкрити потенційні можливості } \\
\text { здійснення особистісно значущого та суспільно прийнятого самовизначенн, } \\
\text { самореалізації та самоутвердження особистості майбутніх учителів }\end{array}$ \\
\hline Технології & $\begin{array}{l}\text { Особистісно-орієнтована спрямованість освітнього процесу на формування } \\
\text { громадянської культури здобувачів передбачає диференціацію структурування } \\
\text { змісту навчального матеріалу. Це обумовлює використання варіативних } \\
\text { навчальних програм з урахуванням характеру майбутньої професійної діяльності } \\
\text { майбутніх учителів іноземної мови. Особистісно-орієнтована спрямованість } \\
\text { навчання передбачає максимальну інтеграцію матеріалу різних навчальних } \\
\text { предметів, використання органічної єдності аудиторної і позааудиторної роботи } 3 \\
\text { індівідуалізації формування громадянської культури здобувачів. }\end{array}$ \\
\hline Результат & $\begin{array}{l}\text { Реалізація особистісно-орієнтованого підходу сприяє розкриттю індивідуальності } \\
\text { кожного здобувача, передбачає, що в центрі уваги знаходиться особистість } \\
\text { студента. Саме до неї адресована система громадянських, правових, моральних } \\
\text { норм і заходи освітнього процесу. }\end{array}$ \\
\hline
\end{tabular}


Таблиця 4.

Реалізація культурологічного підходу до формування громадянської культури майбутнього вчителя іноземної мови

\begin{tabular}{|c|c|}
\hline Трактування & $\begin{array}{l}\text { Культурологічний підхід передбачає вивчення на порівняльній основі способу } \\
\text { життя і варіативності стилів життя країн в культурних спільнотах і } \\
\text { співвіднесених з ними соціальних цінностей, норм, ціннісно-смислових аспектів } \\
\text { духовної та матеріальної культури спільнот, культурної спадщини, культурної } \\
\text { ідентичності та ментальності народів, соціокультурних норм поведінки. }\end{array}$ \\
\hline Актуальність & $\begin{array}{l}\text { Культурологічний підхід набуває особливого значення для формування } \\
\text { громадянської культури, оскільки визначає розуміння життєдіяльності людини як } \\
\text { суб'єкта культури, сформованої в процесі історичного розвитку соціуму, що } \\
\text { відображає духовність, моральність, ідеали, властиві спільності людей }\end{array}$ \\
\hline Мета & $\begin{array}{l}\text { Метою культурологічного підходу є розуміння як своєї, так і іншої культури. } \\
\text { Установка на розуміння як своєї, так і іншої культури, міжкультурне спілкування } \\
\epsilon \text { основною пізнавальною установкою при реалізації культурологічної функції } \\
\text { іноземної мови, в рамках якої культура виступає як сукупність звичаїв, традицій, } \\
\text { звичок, як природна система, мова }\end{array}$ \\
\hline Технології & $\begin{array}{l}\text { Акцент робиться на порівняльному аналізі культур різних народів світу, вивченні } \\
\text { досвіду становлення сучасної цивілізації, пошуку загальнолюдських цінностей і } \\
\text { виділення культурних особливостей. Це сприяє формуванню толерантного } \\
\text { ставлення до представників інших народів і культур, розуміння і поваги } \\
\text { культурного розмаїття. }\end{array}$ \\
\hline Результат & $\begin{array}{l}\text { Культурологічний підхід в навчанні іноземної мови становить наступне: суттєві } \\
\text { особливості соціокультурних структур розкриваються при порівняльному } \\
\text { вивченні мов і національних картин світу; контрастність англійської та } \\
\text { української соціокультурних ситуацій проявляється при порівнянні національної } \\
\text { ментальності обох культур. Вирішення проблем міжкультурної комунікації } \\
\text { пов’язано } з \text { розумінням необхідності викладання іноземної мови } з \text { опорою на } \\
\text { рідну мову і культуру. Культурологічний підхід сприяє збагаченню соціального } \\
\text { досвіду майбутнього вчителя, розвитку у нього розуміння, толерантності, } \\
\text { прийняття, поваги та солідарності по відношенню до конструктивних культурних } \\
\text { відмінностей. }\end{array}$ \\
\hline
\end{tabular}

Отже, суть полікультурного підходу до формування громадянської культури майбутнього вчителя іноземної мови полягає у побудові громадянської освіти в $3 \mathrm{BO} з$ урахуванням соціально-культурних норм, громадянськодемократичних цінностей, домінування культурно значущої взаємодії між субјєктами освітнього процесу.

Діяльнісний підхід у формуванні громадянської культури майбутнього вчителя іноземної мови в сукупності компонентів виходить з уявлень про єдність особистості з ії діяльністю. Ця єдність

Таблиця 5.

Реалізація полікультурного підходу до формування громадянської культури майбутнього вчителя іноземної мови

\begin{tabular}{|c|c|}
\hline Трактування & $\begin{array}{l}\text { Полікультурний підхід до формування громадянської культури майбутнього } \\
\text { вчителя - сукупність дослідницьких методів і засобів, що забезпечують створення } \\
\text { полікультурного середовища ЗВО за рахунок наповнення його цінностями } \\
\text { загальнолюдської, національної та індивідуальної культури, яка включає } \\
\text { майбутнього вчителя в активний процес ії пізнання і творення шляхом } \\
\text { діалогового спілкування, співпраці та самореалізації сутнісних сил і здібностей } \\
\text { особистості в їі культурній та громадянській ідентифікації. }\end{array}$ \\
\hline Актуальність & $\begin{array}{l}\text { Актуальність застосування детермінована змінами, які відбуваються в соціально- } \\
\text { політичній системі країни, наростаючим обсягом інформації, ускладненням } \\
\text { ситуації в міжетнічних відносинах, між різними соціальними системами, які } \\
\text { диктують необхідність вирішення проблеми формування майбутнього вчителя, } \\
\text { здатного жити і здійснювати професійну діяльність }\end{array}$ \\
\hline Мета & $\begin{array}{l}\text { Мета застосування полікультурного підходу полягає в побудові громадянської } \\
\text { освіти в } 3 \mathrm{BO} 3 \text { урахуванням соціально-культурних норм, громадянсько- } \\
\text { демократичних цінностей, домінування культурно значущої взаємодії між } \\
\text { суб'єктами освітнього процесу. }\end{array}$ \\
\hline
\end{tabular}




\section{МЕТОДОЛОГІЧНІ ПІДХОДИ ДО ФОРМУВАННЯ ГРОМАДЯНСЬКОЇ КУЛЬТУРИ В МАЙБУТНІХ УЧИТЕЛІВ ІНОЗЕМНОЇ МОВИ}

\begin{tabular}{|c|c|}
\hline & Продовження таблиці 5. \\
\hline Термінологія & 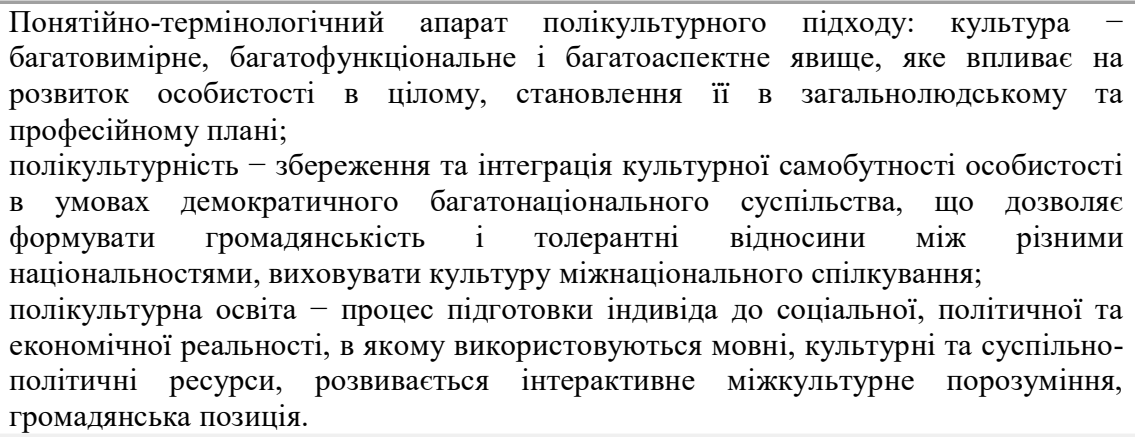 \\
\hline Технології & $\begin{array}{l}\text { Полікультурні критерії відбору змісту освіти: а) відображення гуманістичних } \\
\text { ідей, ідей свободи і ненасильства; б) характеристика унікальних етнічних, } \\
\text { національних самобутніх рис в культурах народу України і світу; в) розкриття в } \\
\text { культурі українського народу загальних елементів традицій, що дозволяють жити } \\
\text { в мирі, злагоді, терпимості, гармонії; г) залучення майбутніх вчителів до світової } \\
\text { культури, розкриття процесу глобалізації, взаємозалежності країн і народів в } \\
\text { сучасних умовах; д) гуманізм; е) демократизм; є) толерантність; ж) } \\
\text { компетентність }\end{array}$ \\
\hline Результат & $\begin{array}{l}\text { Результат застосування полікультурного підходу: людина культури, творча } \\
\text { особистість, що володіє активною громадянською позицією, здатна до активного і } \\
\text { продуктивного життя в полікультурному середовищі }\end{array}$ \\
\hline
\end{tabular}

виявляється у тому, що діяльність в 111 різноманітних формах безпосередньо і опосередковано здійснює зміни в структурах особистості; особистість, зі свого боку, одночасно безпосередньо і опосередковано здійснює вибір адекватних видів і форм діяльності і перетворення діяльності, що задовольняють потреби особистісного розвитку.

Характеристика основних аспектів діяльнісного підходу подана у таблиці 6.

Таблиця 6.
Реалізація діяльнісного підходу до формування громадянської культури майбутнього вчителя іноземної мови

\begin{tabular}{|c|c|}
\hline Трактування & $\begin{array}{l}\text { Діяльнісний підхід в сукупності його компонентів означає з позиції навчальної } \\
\text { організації і управління цілеспрямованою навчальною діяльністю студентів в } \\
\text { загальному контексті їх життєдіяльності спрямованості інтересів, життєвих } \\
\text { планів, ціннісних орієнтацій розуміння сенсу навчання для розвитку творчого } \\
\text { потенціалу }\end{array}$ \\
\hline Актуальність & $\begin{array}{l}\text { Важливість застосування діяльнісного підходу визначається тим, що становлення } \\
\text { громадянської культури особистості можливе тільки в діяльності. Активно } \\
\text { включаючись в соціально значущу громадську діяльність, здобувач розвиває в } \\
\text { собі вміння критично мислити, відстоювати свою точку зору, аналізувати } \\
\text { соціальні проблеми, обирати самостійні рішення, користуватися своїми } \\
\text { громадянськими правами. Даний підхід дає можливість перевірити громадянські } \\
\text { якості здобувачів в реальній громадянській діяльності. }\end{array}$ \\
\hline Мета & $\begin{array}{l}\text { Найважливішою особливістю діяльнісного підходу є його націленість на розвиток } \\
\text { особистості, формування громадянської ідентичності, можливість формування } \\
\text { ціннісних орієнтирів }\end{array}$ \\
\hline Технології & $\begin{array}{l}\text { Освітня сутність даного підходу полягає в тому, що в центрі уваги стоїть не } \\
\text { просто діяльність, а спільна діяльність студентів і викладача з реалізації спільно } \\
\text { вироблених цілей і завдань засвоєння досліджуваного навчального матеріалу. } \\
\text { Освітній процес в цьому аспекті виходить } 3 \text { необхідності проектування, } \\
\text { конструювання та створення ситуацій спільної діяльності. }\end{array}$ \\
\hline Результат & $\begin{array}{l}\text { Діяльність особистості і } є \text { тим механізмом, який дозволяє перетворювати } \\
\text { сукупність зовнішніх впливів у власне розвиваючі зміни, в новоутворення } \\
\text { особистості як продукти розвитку. Реалізація діяльнісного підходу пробуджує } \\
\text { творчий потенціал здобувачів, а також стимулює їх до самостійного вирішення } \\
\text { різних проблем. }\end{array}$ \\
\hline
\end{tabular}




\section{МЕТОДОЛОГІЧНІ ПІДХОДИ ДО ФОРМУВАННЯ ГРОМАДЯНСЬКОЇ КУЛЬТУРИ В МАЙБУТНІХУЧИТЕЛІВ ІНОЗЕМНОЇ МОВИ}

Отже, діяльнісний підхід до формування громадянської культури майбутнього вчителя іноземної мови вимагає спеціальної роботи 3 включення майбутнього педагога в діяльність, 3 переведення його в позицію суб'єкта. Що різноманітніше і продуктивніше значуща для особистості здобувача діяльність, то ефективніше відбувається оволодіння загальнолюдською і вітчизняною культурою, успішніше розвивається і соціалізується особистість, стаючи суб'єктом власної життєтворчості.

Реалізація означеного підходу зумовлює орієнтацію системи професійної підготовки майбутнього педагога на діяльність як на умову $\mathrm{i}$ засіб формування громадянської культури i передбачає включення здобувачів у максимально можливі види діяльності, що забезпечують засвоєння позитивного досвіду професійної діяльності.

Висновки та перспективи подальших розвідок. Отже, методико-технологічний аспект проблеми розвитку громадянської культури майбутнього вчителя розв'язується $з$ позицій різних підходів. У процесі вивчення проблеми стає зрозуміло, що громадянська освіта не може обмежуватися передачею знань від викладача студенту. Розвиток громадянської культури пов'язаний зі спонуканням до вдосконалення, розвитку не тільки професійних, але й особистісних якостей, властивих вчителю іноземної мови. Незважаючи на це, найбільш часто методикотехнологічна основа пропонуються системний, особистісноорієнтований, культурологічний, полікультурний, діяльнісний підходи, які забезпечують на достатньому, 3 погляду визначених суспільством вимог, рівні розв'язання проблеми формування громадянської культури майбутнього вчителя іноземної мови.

Перспективним напрямом подальших досліджень вбачаємо побудову моделі формування громадянської культури майбутнього вчителя іноземної мови 3 використанням запропонованих методологічних підходів.

\section{ЛIТЕРАТУРА}

1. Асмолов А. Г. Стратегия и методология социокультурной модернизации образования. Москва : Федеральный институт развития образования, 2011. 74 с.

2. Вахрушева И. В. Формирование гражданских ценностных ориентации старшеклассников в образовательном процессе : дис. ... канд. пед. наук : 13.00.01. Киров, 2005. 200 с.

3. Демченко Д. І. Формування професійної іншомовної компетентності майбутніх юристів засобами іноземної мови у фаховій підготовці : монографія. Харків : Видавець Іванченко І. С., 2014. 213 с.

4. Дерев'янко Н. Теоретичні основи системного підходу до формування громадянської культури особистості. Наукові записки Тернопільського державного педагогічного інституту. Серія : Педагогіка. 2001. № 4. С. 7-13.

5. Жадан I., Кисельов С., Кисельова О., Рябов С. Політична культура та проблеми громадянської освіти в Україні : метод. посіб. Київ : Тандем, 2004. 80 с.

6. Журова В. Г. Становление гражданской компетентности студенческой молодежи в вузе : дис. ... канд. пед. наук : 13.00.08. Смоленск, 2010. 209 с.

7. Казаева Е. А. Педагогическая концепция развития гражданской позиции будущего учителя : дис. ... д-ра пед. наук : 13.00.08. Челябинск, 2010. $461 \mathrm{c.}$

8. Кравець Р. А. Реалізація полікультурної освіти майбутніх фахівців аграрної галузі на заняттях іноземної мови. Сучасні тендениії та фактори розвитку педагогічних та психологічних наук: матеріали Міжнар. наук.-практ. конф. (Київ, 3-4 лют. 2017 р.). Київ : ГО “Київська наукова організація педагогіки та психології', 2017. С. 90-93.

9. Макарова Е. А. Формирование гражданскопатриотических ценностей у будущих педагогов средствами проектной деятельности : дис. ... канд. пед. наук : 13.00.08. Брянск, 2014. 232 с.

10. Перепеча Н. Н. Формирование гражданской позиции студентов высших учебных заведений : дис. ... канд. пед. наук : 13.00.08. Москва, 2012. 200 с.

11. Попова Т. Н. Педагогические условия формирования профессионально важных качеств у будущих учителей (на материале изучения иностранных языков) : дис. ... канд. пед. наук : 13.00.01. Саратов, 2001. 233 с.

12. Мироненко Т. П. Залучення студентів до громадянських цінностей свого народу. Наукові праці. Серія: Педагогіка. 2000. Т. 7. С. 42-45.

13. Михайліченко М. В. Особистісно зорієнтоване навчання як умова формування громадянськості майбутнього вчителя. Наукові записки : зб. наук. статей Національного педагогічного університету імені М. П. Драгоманова. 2002. Вип. 47. С. 147-151.

14. Москаленко С. В. Педагогическая организация воспитания гражданственности в общеобразовательной школе (на материале преподавания литературы в старших классах) : дис. ... канд. пед. наук : 13.00.01. Москва, 2007. 210 с.

15. Огородник Л. Становлення системи громадянського виховання в умовах розвитку української державності. Проблеми освіти. 2001. Вип. 26. С. 59-64.

16. Подковирофф Н. Т. Міжкультурна освіта в європейських країнах та Україні : монографія / за ред. О. С. Цокур. Одеса : ВМВ, 2017. 72 с.

17. Радул С. Г. Експериментальне дослідження особливостей міжкультурної компетентності у майбутніх вчителів іноземної мови. Ocвіma ma розвиток обдарованої особистості. Серія : Педагогіка. 2013. № 12. С. 56-60.

18. Рогульська О. Модель системи підготовки майбутніх учителів іноземної мови до професійної діяльності в умовах інформаційно-освітнього середовища закладів вищої освіти. Молодь і ринок. 2018. № 11. С. $86-91$.

19. Эрмэ Г. Культура и демократия / пер. с фр. Москва : Прогресс : ЮНЕСКО, 1994. 190 с.

20. Barmer L. Culture and Communication Intercultural 


\section{МЕТОДОЛОГІЧНІ ПДХОДИ ДО ФОРМУВАННЯ ГРОМАДЯНСЬКОЇ КУЛЬТУРИ В МАЙБУТНТХУЧИТЕЛІВ ІНОЗЕМНОЇ МОВИ}

Communication in the Global workplace. Jouranal of business communication. 2018. No. 11. P. 141-161.

21. Bilbeny N. Atica intercultural. La razyn practica frente a los retos de la diversidad cultural. Madrid : Plaza y Valdes, 2012. $204 \mathrm{p}$.

22. Gollnick D., Chinn P. Multicultural Education in a Pluralistic Society. 10th ed. London : Pearson, 2016.352 p.

\section{REFERENCES}

1. Asmolov, A.G. (2011). Strategiya i metodologiya sotsiokulturnoy modernizatsii obrazovaniya [Strategy and methodology of socio-cultural modernization of education]. Moscow, 74 p. [in Russian].

2. Vakhrusheva, I.V. (2005). Formirovanie grazhdanskikh tsennostnykh orientatsii starsheklassnikov v obrazovatelnom protsesse [Formation of civil value orientations of senior pupils in the educational process]. Candidate's thesis. Kirov, 200 p. [in Russian].

3. Demchenko, D.I. (2014). Formuvannia profesiinoi inshomovnoi kompetentnosti maibutnikh yurystiv zasobamy inozemnoi movy u fakhovii pidhotovtsi [Formation of professional and professional competence of maybut lawyers with the help of earthly language in industrial production]. Kharkiv, 213 p. [in Ukrainian]

4. Derevyanko, N. (2001). Teoretychni osnovy systemnoho pidkhodu do formuvannia hromadianskoi kultury osobystosti [Theoretical foundations of the systemic approach to the formation of community culture of particularity]. Scientific Notes. No. 4.pp. 7-13. [in Ukrainian]

5. Zhadan, I., Kiselov, S., Kiselova, O. \& Ryabov, S. (2004). Politychna kultura ta problemy hromadianskoi osvity v Ukraini [Political culture and problems of community education in Ukraine]. Kyiv, 80 p. [in Ukrainian].

6. Zhurova, V.G. (2010). Stanovlenye hrazhdanskoi kompetentnosty studencheskoi molodezhy $\mathrm{v}$ vuze [Formation of civil competence of student youth in the university]. Candidate's thesis. Smolensk, 209 p. [in Russian].

7. Kazaeva, E.A. (2010). Pedahohycheskaia kontseptsyia razvytyia hrazhdanskoi pozytsyy budushcheho uchytelia [Pedagogical concept of development of the future teacher's civic position]. Doctor's thesis. Chelyabinsk, 461 p. [in Russian].

8. Kravets, R.A. (2017). Realizatsiia polikulturnoi osvity maibutnikh fakhivtsiv ahrarnoi haluzi na zaniattiakh inozemnoi movy [Current trends and factors in the development of pedagogical and psychological sciences]. Suchasni tendentsii ta faktory rozvytku pedahohichnykh ta psykholohichnykh nauk: materials Mizhnar. nauk.-practical. conf. (Kyiv, 3-4 years. 2017). - Modern tendencies and factors of development of pedagogical and psychological sciences: Proceedings Intern. Scientific-Practical Conf. (Kyiv, February3-4, 2017). Kyiv, pp. 90-93. [in Ukrainian].

9. Makarova, E.A. (2014). Formyrovanye hrazhdanskopatryotycheskykh tsennostei u budushchykh pedahohov sredstvamy proektnoi deiatelnosty [Formation of civilpatriotic values among future teachers by means of project activities]. Candidate's thesis. Bryansk, 232 p. [in Russian].

10. Perepecha, N.N. (2012). Formirovanie grazhdanskoy pozitsii studentov vysshikh uchebnykh zavedeniy [Formation of civil position of students of higher educational institutions]. Candidate's thesis. Moscow, 200 p. [in Russian].

11. Popova, T.N. (2001). Pedagogicheskie usloviya formirovaniya professionalno vazhnykh kachestv $\mathrm{u}$ budushchikh uchiteley (na materiale izucheniya inostrannykh yazykov [Pedagogical conditions for the formation of professionally important qualities in future teachers (based on the study of foreign languages)]. Candidate's thesis. Saratov, 233 p. [in Russian].

12. Mironenko, T.P. (2000). Zaluchennia studentiv do hromadianskykh tsinnostei svoho narodu [Involving students in the civic values of their nation]. Scientific works. Series: Pedagogy.Vol. 7, pp. 42-45. [in Ukrainian]

13. Mikhailichenko, M.V. (2002). Osobystisno zoriientovane navchannia yak umova formuvannia hromadianskosti maibutnoho vchytelia [Personally oriented education as a condition for the formation of citizenship of the future teacher]. Scientific notes: coll. Science. articles of the National Pedagogical University named after Mykhaylo Drahomanov.Vol. 47.pp. 147-151. [in Ukrainian].

14. Moskalenko, S.V. (2007). Pedagogicheskaya organizatsiya vospitaniya grazhdanstvennosti v obshcheobrazovatelnoy shkole (na materiale prepodavaniya literatury $\mathrm{v}$ starshikh klassakh [Pedagogical organization of civic education in general education school (based on teaching literature in senior grades)]. Candidate's thesis. Moscow, 210 p. [in Russian]

15. Ogorodnik, L. (2001). Stanovlennia systemy hromadianskoho vykhovannia $\mathrm{v}$ umovakh rozvytku ukrainskoi derzhavnosti [Establishment of the system of the community of the community in the minds of the development of the Ukrainian statehood]. Problems of education. Vol. 26. pp. 59-64.[in Ukrainian].

16. Podkoviroff, N.T. (2017). Mizhkulturna osvita v yevropeiskykh krainakh ta Ukraini [Intercultural education in European countries and Ukraine]. Odessa, 72 p. [in Ukrainian].

17. Radul, S.G. (2013). Eksperymentalne doslidzhennia osoblyvostei mizhkulturnoi kompetentnosti u maibutnikh vchyteliv inozemnoi movy [Experimental study of the features of intercultural competence of future foreign language teachers]. Education and development of a gifted personality. Series: Pedagogy. No. 12. pp. 56-60. [in Ukrainian].

18. Rogulska, O. (2018). Model systemy pidhotovky maibutnikh uchyteliv inozemnoi movy do profesiinoi diialnosti $v$ umovakh informatsiino-osvitnoho seredovyshcha zakladiv vyshchoi osvity [The model of the system of preparation of future foreign language teachers for professional activity in the conditions of information and educational environment of higher education institutions].Youth \& market. No. 11. pp. 8691. [in Ukrainian].

19. Erme, G. (1994). Kultura y demokratyia [Culture and Democracy]. Moscow, 190 p. [in Russian].

20. Barmer, L. (2018). Culture and Communication Intercultural Communication in the Global workplace. Jouranal of business communication. No. 11. pp. 141161. [in English].

21. Bilbeny, N. (2012). Attica intercultural. La razyn practica frente a los retos de la diversidad cultural. Madrid, 204 p. [in English].

22. Gollnick, D. \& Chinn, P. (2016). Multicultural Education in a Pluralistic Society. 10th ed. London, 352 p. [in English].

Стаття надійшла до редакції 11.08.2021 